\title{
PENGEMBANGAN MEDIA PEMBELAJARAN TEKNIK DASAR BOLA VOLI UNTUK SISWA SEKOLAH MENENGAH PERTAMA
}

\section{DEVELOPPING LEARNING MEDIA OF VOLLEYBALL BASIC TECHNIQUE FOR JUNIOR HIGH SCHOOL STUDENTS}

\author{
Danang Endarto Putro, Ria Lumintuarsa \\ PPs UNY, Universitas Negeri Yogyakarta \\ juzz.juzz88@gmail.com, -
}

\begin{abstract}
Abstrak
Penelitian ini bertujuan untuk menghasilkan media pembelajaran teknik dasar bola voli untuk siswa SMP. Penelitian ini menggunakan desain penelitian dan pengembangan. Langkah-langkah yang dilakukan sebagai berikut; (1) melakukan analisis kebutuhan, (2) mengembangkan instrumen penilaian, (3) mengembangkan dan memilih bahan materi, (4) merancang dan melakukan evaluasi formatif, dan (5) penyusunan produk akhir. Uji coba dengan skala kecil dilakukan terhadap 30 siswa SMP Negeri 1 Jetis, sedangkan uji coba skala besar sebanyak 57 siswa dengan rincian 28 siswa SMP Negeri 1 Bantul dan 29 siswa SMP Negeri 1 Imogiri. Penilaian kualitas produk melibatkan 3 orang guru pendidikan jasmani. Instrumen yang digunakan untuk mengumpulkan data antara lain: (1) petunjuk umum wawancara, (2) angket skala nilai validasi, dan (3) angket skala nilai pedoman kualitas media pembelajaran. Hasil penelitian adalah sebagai berikut: (1) data hasil validasi menurut ahli materi adalah "Sangat Baik", (2) menurut ahli media adalah "Sangat Baik", (3) penilaian siswa secara keseluruhan adalah "Sangat Baik". (4) penilaian guru terhadap kualitas produk media pembelajaran dengan kriteria "Sangat Baik". Pada uji keefektivan media pembelajaran diperoleh rerata pretest sebesar 5,4 dan posttest sebesar 8,6.
\end{abstract}

Kata kunci: media pembelajaran, teknik dasar bola voli.

\begin{abstract}
This study aims to produce learning media of volleyball basic technique for junior high scholl students. The study used research and development design. The prosedures were done as follow: (1) doing need analysis, (2) developing assessment instruments, (3) developing and selecting instructional materials, (4) designing and conducting formative evaluation of instruction, and (5) making final product. The small scale trial was conducted to 30 students of SMP N 1 Jetis, while the bigger scale trial was done to 57 students (28 students of SMP N 1 Bantul and 29 of SMP N 1 Imogiri). Product quality assessment involves 3 physical education teachers. The instruments which were used in collecting data were: (1) general interview instruction, (2) validation scale questionnaire, and (3) questionnaire of quality scale of the learning media. The research show that the validations; (1) from material expert is very good, (2) from media expert is very good, (3) from overall students is very good, (4) from teacher is very good. The effectiveness of learning media was 5.4 on pretest and 8.6 on posttest.
\end{abstract}

Keywords: learning media, basic techniques volleyball. 


\section{Pendahuluan}

Perkembangan teknologi erat kaitanya dengan kemajuan ilmu pengetahuan. Ilmu Pengetahuan dan Teknologi (IPTEK) merupakan unsur untuk mencetak sumber daya manusia berkualitas. IPTEK merupakan salah satu materi pengajaran sebagai bagian dan pendidikan. Peran pendidikan dalam mewariskan dan mengembangkan IPTEK sangat penting. Pendidikan menjadi salah satu tumpuan masyarakat untuk menjadikan pribadi yang unggul. Pendidikan mengajari anak untuk dapat berfikir kreatif dan inovatif. Pendidikan menempa setiap individu untuk kuat dalam menghadapi era globalisasi.

Era globalisasi menekankan kebutuhan IPTEK menjadi hal yang utama dibandingkan dengan era-era sebelumnya. Setiap individu dituntut untuk dapat mengoperasionalkan peralatan moderen. Metode pembelajaran dalam dunia pendidikan dapat dihadirkan dengan menggunakan alat peraga pembelajaran atau sering disebut dengan media pembelajaran. Namun terkadang alat peraga yang digunakan masih kurang menarik dikarenakan monoton dan kurang atraktif. Salah satu metode pembelajaran yang sekarang ini dapat dikembangkan adalah dengan memanfaatkan teknologi komputer sebagai media pembelajaran.

Perkembangan teknologi komputer terutama dalam bidang perangkat lunak yang semakin besar sangat mendukung dalam penerapan sebuah media sebagai sarana kegiatan belajar mengajar. Melalui sarana komputer dapat disajikan berbagai macam media pembelajaran yang memuat materi pembelajaran secara tekstual, audio maupun visual. Berbagai macam tampilan dapat dibuat untuk menarik minat siswa.

Namun pada kenyataanya, perkembangan teknologi yang begitu pesat, belum digunakan secara optimal pada proses pembelajaran pendidikan jasmani di sekolah. Guru lebih banyak menggunakan metode pembelajaran konvensional untuk menyampaikan materi kepada siswa. Dengan demikian perkembangan IPTEK yang sedemikian pesat tidak mampu di terapkan secara maksimal dalam proses pembelajaran.

Pendidikan Jasmani Olahraga dan Kesehatan adalah salah satu dari sekian mata pelajaran yang disampaikan di Sekolah Menengah Pertama. Bola voli masuk dalam kurikulum Sekolah Menengah Pertama (SMP) dan menjadi cabang olahraga wajib yang harus dipelajari oleh semua peserta didik. Teknik dasar mencakup servis, pasing, smash dan membendung (blocking). Melalui bola voli juga diharapkan menumbuhkan nilai-nilai seperti kejujuran, sportifitas, pantang menyerah dan tanggung jawab. Media pembelajaran menjadi salah satu alat yang bisa digunakan guru untuk menyampaikan materi. Daya tarik siswa terhadap materi pelajaran yang disampaikan dengan interaktif seyogyanya dapat meningkatkan kualitas pembelajaran.

Fakta yang ditemukan di lapangan hasil observasi dan wawancara menunjukkan bahwa pemanfaatan komputer dalam pembelajaran Penjasorkes belum maksimal. Guru lebih memilih untuk tidak mengadakan pembelajaran teori dibandingkan dengan praktik karena persepsi guru Penjasorkes tentang pembelajaran masih terkonsep pada praktik lapangan. Guru selalu mengajarkan siswa hanya pada keterampilan praktik saja, akan tetapi dasar teori dari suatu keterampilan gerak belum bisa diberikan secara teoritis tidak terkecuali pada materi bola voli. Pembelajaran yang menyeluruh seharusnya diajarkan dengan tahapan yang runtut dan berkesinambungan. Dalam kontek tersebut pembelajaran seharusnya diberikan melalui pembelajaran teori dan praktik.

Siswa Sekolah Menengah Pertama merupakan waktu di mana aktivitas banyak dilakukan dengan menggabungkan antara teknik, bermain dan bergerak yang semakin membuat guru harus berfikir ekstra untuk menyampaikan materi pembelajaran. Melalui sebuah media pembelajaran, seyogyanya akan mempermudah proses penyampaian materi kepada siswa. Materi yang dikemas dengan cantik, menarik dan penyampaian yang interaktif tentunya akan menambah daya tarik siswa kepada mata pelajaran. Daya tarik siswa akan mewujudkan suasana belajar yang efektif. Segala cara dan metode yang dikemas dalam media tersebut diharapkan berujung pada prestasi belajar maksimal.

Berdasarkan kenyataan di atas, maka peneliti mengembangkan media pembelajaran teknik dasar bola voli untuk siswa Sekolah Me-nengah Pertama. Media dikembangkan dan di-sesuaikan dengan kurikulum Sekolah Menengah Pertama yang di dalamnya terdapat beberapa teknik dasar permainan bola voli. Media disusun dengan menggabungkan teori mengenai teknik dasar bola voli, gambar, video, dan bentuk pembelajaran. Peneliti mengaharapkan 
produk media yang dihasilkan dapat: (1) menambah variasi media pembelajaran bagi siswa Sekolah Menengah Pertama, (2) memotivasi guru untuk dapat memanfaatkan fasilitas komputer dalam proses pembelajaran, (3) membantu guru dalam proses pembelajaran bola voli.

Pengembangan adalah upaya pendidikan baik formal maupun nonformal yang dilaksanakan secara sadar, berencana, terarah, teratur dan bertanggung jawab dalam rangka memperkenalkan, menumbuhkan, membimbing, mengembangkan suatu dasar kepribadian yang seimbang, utuh, selaras, pengetahuan, keterampilan sesuai dengan bakat, keinginan serta kemampuan-kemampuan, sebagai bekal atas prakarsa sendiri untuk menambah, meningkatkan, mengembangkan diri ke arah tercapainya martabat, mutu dan kemampuan manusiawi yang optimal serta pribadi mandiri. Pengembangan yang dilakukan adalah salah satu bentuk kreatifitas manusia untuk mendapatkan produk baru. Nafsu manusia yang tidak pernah merasa cukup menjadikannya pondasi untuk terus memperbaiki ataupun membuat baru suatu barang yang sudah maupun belum pernah ada.

Mulyati (2005, p.5) bahwa belajar merupakan suatu usaha sadar individu untuk mencapai tujuan peningkatan diri atau perubahan diri melalui latihan-latihan dan pengulanganpengulangan dan perubahan yang terjadi bukan karena peristiwa kebetulan.

Proses kegiatan belajaran mengajar memerlukan cara yang tepat untuk menghasilkan prestasi yang maksimal, salah satunya adalah dengan menggunakan metode pembelajaran. Metode pembelajaran merupakan suatu cara yang dilakukan oleh seorang guru pada saat proses kegiatan belajar mengajar berlangsung untuk menyampaikan materi kepada siswa-siswinya di Sekolah. Salah satu keterampilan guru yang memegang posisi penting adalah keterampilan memilih metode pembelajaran. Pemilihan metode pembelajaran berkaitan langsung dengan usaha guru dalam menampilkan pengajaran sesuai dengan situasi dan kondisi, sehingga tujuan pembelajaran dapat tercapai secara optimal (Fathurrohman, 2007, p.55).

Metode megajar pada umumnya ditujukan untuk membimbing peserta didik dalam belajar sesuai dengan bakat dan kemampuan masing-masing. Efektifitas penggunaan metode pembelajaran tergantung pada kesesuaian metode pembelajaran dengan tujuan pembela- jaran, materi pembelajaran, kemampuan guru, kondisi peserta didik, sarana dan prasarana, situasi dan kondisi serta waktu (Sumiati, 2008, pp.91-92).

Menurut Mahendra (2003, p.4) pendidikan Jasmani pada hakikatnya adalah proses pendidikan yang memanfaatkan aktivitas fisik untuk menghasilkan perubahan holistik dalam kualitas individu, baik dalam hal fisik, mental, serta emosional.

Physical Education is the process by which changes in the individual are bought about through movements experiences (http://bodyfitnesshealth.com/meaning-anddefinition-of-physical-education/). Pengertian pendidikan jasmani merupakan sebuah proses adanya perubahan dalam individu yang didapat melalui pengalaman gerakan. Physical Education aims not only at physical development but is also concerned with education of the whole person through physical activities (http://bodyfitnesshealth.com/meaning-and-definitionof-physical-education/). Pendidikan Jasmani ber-tujuan tidak hanya pada pembangunan fisik tetapi juga peduli dengan pendidikan keseluruhan melalui kegiatan fisik. Melalui aktivitas gerak seorang sisiwa akan mendapatkan pengalaman yang akan digunakan dalam kehidupan sehari-hari. Aktivitas jasmani juga dapat memberikan manfaat bagi tercapainya kesehatan jasmaniah dan batiniah.

Pendidikan Jasmani juga sebagai wahana untuk mengembangkan keterampilan kognitif, afektif, psikomotor, sosial serta psikis siswa melalui aktivitas fisik yang dilakukan secara terencana. Pendidikan Jasmani juga sebagai saran dalam membentuk karakter siswa yang diterapkan secara sistematis dan berkelanjutan. Pembentukan karakter bertujuan untuk meningkatkan mutu penyelenggaraan dan hasil pendidikan di sekolah.

Smaldino, Lowther, \& Russell (2008, p.372) menyatakan bahwa "medium, a means of communication. Derived from the latin medium (between) the ters refers to anything that carries information between a source and a receiver. Media merupakan sebuah komunikasi yang melibatkan dua pihak yaitu antara sumber dan penerima. Media pembelajaran berguna untuk memperlancar interaksi antara guru dengan siswa sehingga kegiatan pembelajaran lebih efektif dan efisien. Berbagai macam variasi media untuk menyampaikan materi dibuat dalam rangka mempermudah proses pembelajaran. Media merupakan wahana yang 
dapat mempermudah penyampaian materi dalam proses kegiatan belajar mengajar.

Winataputra (2005, p.55) mengemukakan beberapa alasan mengapa media pembelajaran sangat penting sehingga harus terintegrasi dalam proses kegiatan belajar mengajar, yaitu: (1) Proses pembelajaran akan lebih berhasil diperoleh bila siswa turut aktif dalam pembelajaran tersebut, dan hal ini hanya dapat terjadi dengan adanya media; (2) Rata-rata jumlah informasi yang diperoleh seseorang melalui indera memiliki komposisi sebagai berikut; (a) 75\% melalui penglihatan atau visual, (b) $13 \%$ melalui pendengaran atau audio, (c) 6\% melalui sentuhan, (d) melalui penciuman dan pengecap; (3) Pengetahuan yang dapat diingat seseorang antara lain bergantung pada melalui indera apa ia memperoleh pengetahuannya.

Media pembelajaran dapat memberikan kesamaan pengalaman kepada siswa tentang peristiwa-peristiwa di lingkungan sekitar, serta memungkinkan terjadinya interaksi langsung dengan guru, masyarakat, dan lingkungannya. Melalui media yang dikemas dengan menarik dapat membuat para siswa-siswi terpukau, sehingga tingkat konsentrasi terhadap penyampaian materi akan lebih tinggi. Hal tersebut dimaksudkan untuk mencapai hasil yang lebih baik dibandingkan tanpa menggunakan media pembelajaran. Walker \& Hess (2000, p.206) menyatakan bahwa untuk mengetahui kualitas media pembelajaran harus dilihat dari beberapa kriteria sebagai berikut: (1) Kualitas materi dan tujuan yang meliputi ketepatan, kelengkapan, kepentingan, keseimbangan, daya tarik, kewajaran, dan kesesuaian dengan situasi peserta didik; (2) Kualitas pembelajaran, yang meliputi memberikan kesempatan belajar, memberikan untuk belajar, kualitas memotivasi, fleksibilitas instruksional, hubungan dengan program pembelajaran lainnya, kualitas tes dan penilaiannya dapat memberikan dampak bagi peserta didik, dan dapat memberikan dampak bagi guru serta proses pembelajaran.

Newby, et all (2004, p.116) menyatakan bahwa untuk mengetahui kualitas media pembelajaran harus mempertimbangkan tiga hal, yaitu: (1) Method, yaitu teknik dan prosedur yang digunakan dalam pembelajaran; (2) Media, yaitu media yang digunakan dalam pembelajaran untuk menarik minat peserta didik; (3) Material, yaitu sisi pembelajran yang meliputi motivasi, orientasi, informasi, aplikasi, dan evaluasi.

Teori Koneksionisme menyebutkan konsep transfer of training, yaitu hasil kecapakan yang telah diperoleh dalam belajar dapat digunakan untuk memecahkan masalah lain. Diharapkan apabila seseorang sudah mempunyai kecakapan yang dipelajarinya dari dunia formal dapat mengaplikasikannya di masyarakat. Hal tersebut adalah salah satu bentuk serta fungsi dari kecakapan sosial yang dimiliki oleh setiap individu dan hasil dari proses belajar. Sedangkan Skinner berpendapat bahwa proses belajar memerlukan usaha untuk menimbulkan dan mengembangkan respon agar memperoleh suatu penguatan.

Menurut Jean Peaget siswa Sekolah Menengah Pertama berada pada tahap periode operasi formal dengan rentang usia dari 11 tahun sampai dewasa. Periode operasi formal merupakan tingkat puncak perkembangan struktur kognitif, anak remaja mampu berpikir logis untuk semua jenis masalah hipotesis, masalah verbal serta dapat menggunakan penalaran ilmiah dan dapat menerima pandangan orang lain.

Menurut Bruner (Sugihartono, 2007, pp.111-112) faktor-faktor yang harus diperhatikan dalam belajar adalah: (1) Guru harus bertindak sebagai fasilitator, mengecek pengetahuan yang dimiliki siswa sebelumnya, menyediakan sumber-sumber belajar dan menanyakan pertanyaan yang bersifat terbuka; (2) Siswa membangun pemaknaannya melalui eksplorasi, manipulasi dan berpikir; (3) Penggunaan teknologi dalam pengajaran, siswa sebaiknya melihat bagaimana teknologi tersebut bekerja daripada hanya sekedar diceritakan oleh guru.

Kemajuan ilmu pengetahuan dan teknologi menambah keberagaman software. Berbagai macam software banyak dikembangakan untuk memenuhi kebutuhan kerja diberbagai profesi. Salah satu software yang juga dikembangakan adalah Adobe Flash Profesional CS5. Adobe Flash Profesional CS5 mengkombinasikan desain yang ekspresif, seperti mesin teks multilingual baru serta efek yang lebih menakjubkan dengan pengembangan yang dapat diperpanjang dan pilihan yang lebih maju.

Adobe Flash Professional CS5 is an authoring tool that you can use to create presentations, applications, and other content that responds to user interaction. Flash projects can include simple animations, video 
content, complex user interfaces, applications, and everything in between. In general, individual projects created with Flash Professional are called applications (or SWF applications), even though they might only contain basic animation. You can make media-rich applications by including pictures, sound, video, and special effects (http://www.adobe.com/devnet/flash/articles/flash_cs5_createfla.html).

Adobe Flash Professional CS5 sebagai salah satu software authoring yang dapat digunakan untuk membuat presentasi, aplikasi dan konten lainnya yang merespon interaksi kepada pengguna. Proyek flash dapat mencakup animasi sederhana, konten video, user interface yang kompleks, aplikasi, dan sebagainya. Secara umum, proyek-proyek individu yang dibuat dengan Flash Professional disebut aplikasi (atau aplikasi SWF). Walau berisi animasi dasar, tetapi dengan bantuan software Adobe Flash Profesional CS5 dapat dibuat sebuah media yang kaya aplikasi dengan memasukkan unsur materi berupa gambar, suara, video dan efek khusus. Produk media pembelajaran berisikan materi-materi dalam bentuk video, gambar dan animasi lainnya yang dihasilkan dari software ini diharapkan dapat mempermudah penggunaan dan meningkatkan minat siswa saat proses pembelajaran.

Volleyball is an interactive game and can be divided into the two main phases of attack and defense, each having three or four sequential skill events that are expected to occur sequentially in a hierarchical order (Bergeles, 2010, p.28). Pengertian tersebut menunjukkan bahwa bola voli merupakan sebuah permainan interaktif dan dapat dibagi menjadi dua fase yaitu fase serangan dan fase bertahan dimana masing-masing memiliki tiga atau empat macam keterampilan yang saling melengkapi. Keterampilan tersebut dapat diartikan sebagai posisi pemain, ada yang menjadi penyerang, pengumpan dan pertahanan. Permainan bola voli mengharuskan setiap individu untuk bisa melakukan gerak teknik dasar. Gerak teknik dasar tersebut antara lain passing, servis, smash dan membendung (blocking). Bagi individu yang dapat menguasai gerakan teknik dasar tersebut tentunya akan mendukung kinerja siswa saat praktik bermain.

Tujuan dari permainan bola voli seperti dinyatakan oleh Vaibhav Rai (2013, p.236) the game of volleyball offers opportunities for the development of strength, endurance, speed, agility, and neuro-muscular skills and immediate action along with many precise educational outcomes. Permainan bola voli memberikan kesempatan untuk dapat mengembangkan kekuatan, daya tahan, kecepatan, kelincahan, keterampilan dan berbagai macam manfaat untuk mendapatkan pendidikan yang baik. Selain melatih keterampilan fisik, dengan pembelajaran bola voli siswa diharapkan dapat menyerap manfaat sebagai pengalaman gerak untuk mensukseskan tercapainya tujuan pendidikan.

Hal tersebut menjadi tantangan bagi guru penjas untuk meramu proses kegiatan belajar menjadi sebuah kegiatan yang menyenangkan dan membahagiakan bagi kedua belah pihak. Seorang guru pendidikan jasmani harus bisa memanfaatkan karakteristik siswa Sekolah Menengah Pertama dimana rasa keingintahuan pada hal baru yang belum pernah ditemui sebelumnya bisa mengakibatkan perilaku baru yaitu mulai memunculnya karakter diri perlu diberikan stimulus agar dapat tersalurkan dengan baik melalui proses pembelajaran. Rasa keingintahuan tersebut harus di arahkan menuju perilaku positif untuk mendapatkan pengalaman belajar yang mendukung pengembangan perilaku, kepribadian serta ilmu pengetahuan.

\section{Metode}

Penelitian ini merupakan penelitian dan pengembangan (Research and Development) yang akan menghasilkan sebuah produk. Berdasarkan penjelasan Gall, Gall, \& Borg (2003, p.569) bahwa penelitian dan pengembangan menggunakan temuan penelitian untuk merancang prosedur dan produk baru, kemudian secara sistematis diuji di lapangan, dievaluasi, dan disempurnakan sampai memenuhi kriteria tertentu dari unsur efektivitas, kualitas, atau standar yang sama.

Muatan materi yang ada di dalam media pembelajaran berupa, gambar, video teknik dasar dari cabang olahraga bola voli. Keseluruhan materi tersebut kemudian ditampilkan dengan visualisasi yang menarik sehingga target pengguna dari produk ini tertarik dan mudah menangkap inti sari dari materi tersebut. Produk yang dihasilkan nantinya dapat digunakan untuk mempermudah penyampaian materi dalam pembelajaran teknik dasar bola voli.

Prosedur pengembangan yang akan dilaksanakan dalam pengembangan ini mengacu langkah pengembangan Borg \& Gall yang diringkas oleh pengembang menjadi 5 langkah yaitu: (1) melakukan analisis kebutuhan, (2) 
mengembangkan instrument penilaian, (3) mengembangkan dan memilih bahan materi, (4) merancang dan melakukan evaluasi formatif, (5) penyusunan produk akhir. Pengklasifikasian sepuluh langkah menjadi lima langkah tidak mengurangi esensi materi, namun dimaksudkan untuk mempermudah pemahamam kosep.

Kelima langkah tersebut oleh peneliti dikelompokkan menjadi;

\section{Melakukan Analisis Kebutuhan}

Berdasarkan temuan saat proses pembelajaran peneliti mengemukakan asumsi bahwa seorang guru tidak selalu memberikan penekanan teori gerak pada teknik yang diajarkan. Beberapa alasan yang diutarakan oleh guru adalah belum adanya media pembelajaran yang bisa digunakan untuk mendukung proses penyampaian materi teori. Keberadaan fasilitas komputer juga belum teroptimalkan penggunaannya dalam proses kegiatan belajar mengajar terkhusus mata pelajaran Penjasorkes. Materi bola voli merupakan salah satu bahan ajar yang sebagian besar selalu dilakukan dengan praktek di lapangan.

Studi pendahuluan untuk menganalisa lebih lanjut mengenai kebutuhan yang dilakukan melalui observasi dan wawancara terhadap tiga guru SMP. Selain itu, peneliti melakukan studi pustaka untuk mempelajari kurikulum SMP, hasil penelitian yang relevan, dan teori yang berkaitan dengan penelitian. Informasi dari hasil observasi, wawancara, dan studi pustaka kemudian dianalisis untuk memfokuskan aspek-aspek yang akan menjadi dasar pengembangan media pembelajaran teknik dasar bola voli untuk siswa SMP

\section{Mengembangkan Instrumen Penilaian}

Instrumen penilaian produk digunakan untuk mendapatkan data hasil penilaian. Instrumen yang berbentuk angket digunakan untuk mendapatkan validasi yang dilakukan ahli materi, ahli media, uji coba skala kecil dan uji coba skala besar serta butir soal untuk uji keefektivitasan media pembelajaran. Sedangkan untuk melakukan wawancara, dibuat panduan pertanyaan untuk mendapatkan informasi yang akurat dari guru penjas. Analisis terhadap hasil wawancara dilakukan untuk mengetahui kebenaran asumsi peneliti dari kondisi nyata di lapangan mengenai permasalahan yang ada.
Mengembangkan dan Memilih Bahan Materi

Pada tahap ini pengembang melakukan langkah-langkah; (a) menetapkan standar kompetensi, (b) merumuskan kompetensi dasar, (c) mentukan strategi pembelajaran, (d) menentukan materi pembelajaran dan (e) menentukan bentuk evaluasi. Pada tahap ini pengembang juga melakukan langkah-langkah; (a) membuat alur pengembangan, (b) mengumpulkan bahan pendukung, (c) membuat desain dan (d) memproduksi awal.

Materi yang dipilih merupakan bahan ajar yang terdapat di kurikulum SMP dengan materi bola voli. Teknik dasar menjadi materi utama yang diberikan untuk siswa SMP. Materi teknik dasar bola voli di SMP mencakup teknik dasar pasing atas, pasing bawah, servis atas, servis bawah, smash, dan membendung (blocking). Beberapa bentuk latihan yang berkaitan dengan teknik dasar bola voli di atas akan dibuat dalam bentuk video.

Merancang dan Melakukan Evaluasi Formatif

Selama produk dalam masa pengembangan selalu dilakukan perbaikan dengan merujuk pada proses evaluasi dan validasi. Proses evaluasi dan validasi berfungsi untuk memberikan masukan serta perbaikan untuk meningkatkan efektifitas produk (Gall, Gall, \& Borg, 2003, p.570).

\section{Penyusunan Produk Akhir}

Hasil penilaian dan saran perbaikan terhadap uji coba skala besar beserta catatan lapangan digunakan sebagai materi revisi media pembelajaran untuk menyusun produk akhir. Produk akhir yang dihasilkan berbentuk CD media pembelajaran teknik dasar bola voli untuk siswa Sekolah Menengah Pertama dengan materi di dalamnya adalah teknik pasing, servis, smash, dan membendung (blocking). Media pembelajaran tentunya layak digunakan sebagai sarana penyampaian materi oleh guru Penjasorkes dalam proses kegiatan belajar mengajar serta untuk belajar mandiri siswa saat di luar jam pelajaran.

Waktu dan Tempat Penelitian

Pelaksanaan penelitian dilakukan pada tanggal 11-29 juni 2013. Tempat penelitian di SMP Negeri 1 Jetis, SMP Negeri 1 Bantul dan SMP Negeri 1 Imogiri. 
Subjek Uji Coba

Uji coba dengan skala kecil menggunakan subjek 30 siswa di SMP N 1 Jetis. Subjek uji coba dengan skala besar menggunakan 28 siswa di SMP N 1 Bantul dan 29 siswa di SMP N 1 Imogiri.

Jenis Data

Data yang diperoleh dari penelitian ini merupakan data kuantitatif yang akan diubah menjadi data kualitatif. Data tersebut digunakan untuk memberi gambaran mengenai kualitas multimedia pembelajaran yang dikembangkan, antara lain berupa isi/materi pembelajaran, kaulitas materi pembelajaran, kualitas teknik tampilan dan pemrograman produk.

Instrumen Pengumpulan Data

Instrumen yang digunakan untuk mengumpulkan data pada penelitian ini berupa pedoman wawancara, angket dan butir soal. Pedoman wawancara berisi daftar pertanyaan yang merupakan garis besar tentang hal mendasar yang akan ditanyakan. Instrumen angket disusun untuk mengetahui kualitas produk yang dihasilkan. Angket berisi daftar pernyataan disertai skala nilai digunakan untuk memberikan penilaian pada validasi ahli materi, media serta uji coba skala kecil dan besar. Butir pertanyaan untuk uji keefektivan produk yang akan dilakukan pada pretest dan posttest. Penelitian ini akan menggunakan Skala Likert dengan skala 5; (1) sangat kurang, (2) kurang baik, (3) cukup baik, (4) baik, dan (5) sangat baik. Skala Likert merupakan skala penilaian untuk menilai pendapat, sikap, dan pandangan (Riduwan, 2007, p.12).

\section{Teknik Analisis Data}

Data yang diperoleh melalui kegiatan uji coba diklasifikasikan menjadi dua, yaitu data kuantitatif dan kualitatif. Data kualitatif berupa saran-saran yang dikemukakan oleh ahli media, dan siswa kemudian dihimpun untuk perbaikan multimedia pembelajaran ini. Teknik analisis data dalam penelitian ini menggunakan dua langkah, yaitu menganalisis data mengenai kelayakan serta mengetahui keefektifan produk media yang telah dikembangkan. Skor yang diperoleh kemudian dikonversikan menjadi nilai dengan skala 5 yang disajikan pada tabel 1 (Sukardjo, 2005, p.53).
Tabel 1. Kriteria Penilaian

\begin{tabular}{|c|c|c|c|}
\hline \multirow{2}{*}{ Nilai } & \multirow{2}{*}{ Kriteria } & \multicolumn{2}{|c|}{ Skor } \\
\hline & & Rumus & Perhitungan \\
\hline A & $\begin{array}{l}\text { Sangat } \\
\text { Baik }\end{array}$ & $\mathrm{X}>\bar{X} i+1,8 \mathrm{Sb}_{\mathrm{i}}$ & $X>4,21$ \\
\hline B & Baik & $\begin{array}{c}\bar{X} \iota+0,6 \\
\mathrm{Sb}_{\mathrm{i}}<\mathrm{X} \leq \bar{X} \iota+1,8 \mathrm{Sb}_{\mathrm{i}}\end{array}$ & $3,40<X \leq 4,21$ \\
\hline $\mathrm{C}$ & $\begin{array}{l}\text { Cukup } \\
\text { Baik }\end{array}$ & $\begin{array}{c}\bar{X} \mathrm{l}-0,6 \\
\mathrm{Sb}_{\mathrm{i}}<\mathrm{X} \leq \bar{X} \iota+0,6 \mathrm{Sb}_{\mathrm{i}}\end{array}$ & $2,60<X \leq 3,40$ \\
\hline D & $\begin{array}{l}\text { Kurang } \\
\text { Baik }\end{array}$ & $\begin{array}{c}\overline{X l}-1,8 \\
\mathrm{Sb}_{\mathrm{i}}<\mathrm{X} \leq \bar{X} \mathrm{l}-0,6 \mathrm{Sb}_{\mathrm{i}}\end{array}$ & $1,79<X \leq 2,60$ \\
\hline $\mathrm{E}$ & $\begin{array}{l}\text { Sangat } \\
\text { Kurang }\end{array}$ & $\mathrm{X} \leq \bar{X} i-1,8 \mathrm{Sb}_{\mathrm{i}}$ & $X \leq 1,79$ \\
\hline
\end{tabular}

\section{Hasil Penelitian dan Pembahasan}

Pada produk awal disetiap materi terdapat tombol untuk memilih materi pada media antara lain; (1) Pendahuluan, isi dari pendahuluan adalah standar kompetensi, kompetensi dasar, dan tujuan pembelajaran, (2) Pengantar, isi dari pengantar adalah sejarah bola voli dan sarana dan prasarananya, (3) Materi, isi dari materi adalah tehnik dasar pasing atas, pasing bawah, servis atas, servis bawah, smash, blocking dan kombinasi beserta video pembelajarannya, (4) Evaluasi, berisi soal evaluasi terkait dengan materi pembelajaran. (5) Profil, isi dari profil adalah berupa keterangan dari peneliti, pembimbing, ahli materi, ahli media dan para model.

Produk awal media belajar didesain dengan menggunakan beberapa software desain grafis, video editing, animasi, dan converter. Software yang digunakan untuk membuat produk media belajar ini adalah Microsoft Word For Mac 2011, Corel Draw X5, Adobe Photoshop CS 6, Final Cut Pro, Sony Sound 7.0 dan Adobe Flash CS 6.

Setelah melewati tahapan pembuatan produk awal kemudian dinilai aspek kualitas materi pembelajaran dan aspek isi oleh ahli materi. Ahli materi yang menjadi validator dalam penelitian ini adalah Prof. Dr. Suharjana, M.Kes. AIFO. Beliau adalah dosen Fakultas Ilmu Keolahragaan dan Ilmu Keolahragaan Pascasarjana Universitas Negeri Yogyakarta. Peneliti memilih beliau karena kompetensi dalam bidang olahraga bola voli. Data diperoleh dengan cara menanyangkan media belajar 
menggunakan laptop dan memberikan lembar evaluasi. Selanjutnya ahli materi menjalankan program media belajar dan setelah itu memberikan masukan secara tertulis maupun secara lisan mengenai materi yang ada di dalam media pembelajaran. Aspek kebenaran pembelajaran merupakan informasi yang meliputi bagian yang salah, jenis kesalahan, dan saran perbaikan. Aspek-aspek tersebut berguna untuk kepentingan penelitian kualitas produk media belajar yang sedang dikembangkan, oleh karena itu saran dari ahli materi sangat dibutuhkan.

Hasil validasi dan penilaian ahli materi terhadap media yang dikembangkan dan saran dibuat untuk produk awal. Penilaian diberikan dengan melihat dan mencermati media belajar yang telah dibuat, selanjutnya saransaran yang telah diberikan berupa penambahan materi dan penyesuaian materi sesuai dengan standar kompetensi dan kompetensi dasar Sekolah Menengah Pertama (SMP) yang tertera pada silabus kelas 7,8 dan 9. Saran yang diberikan oleh ahli materi berupa penekanan dan tata kelola proses pemberian materi latihan yang ada saat proses pembelajaran. Perbaikan sudah dilakukan pada penempatan bentuk latihan melalui tata saji yang menampilkan gerakan dari mudah menuju gerakan kompleks. Hal tersebut dapat dilihat dalam menu materi di mana bentuk latihan dimulai dari latihan individu menuju latihan berkelompok. Hasil penilaian ahli materi secara detail dapat dilihat pada Tabel 2 di bawah ini.

Tabel 2. Hasil Penilaian Kualitas Produk Media oleh Ahli Materi

\begin{tabular}{|c|c|c|c|}
\hline Aspek Penilaian & $\begin{array}{l}\text { Jumlah } \\
\text { Rerata }\end{array}$ & Rerata & Kategori \\
\hline $\begin{array}{l}\text { Aspek Kualitas } \\
\text { Materi Pembelajaran }\end{array}$ & 59,00 & 4,54 & $\begin{array}{l}\text { Sangat } \\
\text { Baik }\end{array}$ \\
\hline Aspek Isi & 52,00 & 4,33 & $\begin{array}{l}\text { Sangat } \\
\text { Baik }\end{array}$ \\
\hline Jumlah & & 8,87 & \\
\hline Rerata keseluruhan & & 4,44 & $\begin{array}{l}\text { Sangat } \\
\text { Baik }\end{array}$ \\
\hline
\end{tabular}

Berdasarkan Tabel 2, rerata penilaian hasil validasi ahli materi pada aspek kualitas pembelajaran sebesar 4,54 termasuk ketegori "Sangat Baik". Rerata penilaian aspek isi sebesar 4,33 termasuk kriteria "Sangat Baik". Rerata keseluruhan hasil validasi ahli materi sebesar 4,44 termasuk kriteria "Sangat Baik".
Penilaian selanjutnya dilakukan oleh ahli media. Penilaian meliputi aspek tampilan dan aspek pemrograman. Ahli media yang menjadi validator dalam penelitian ini adalah Herrymawan Indra Wibisono, S.Ikom. Beliau adalah seorang yang sudah lama berkecimpung di dunia foto dan video. Peneliti memilih beliau karena kompetensi dalam bidang fotografi dan videografi sudah tidak bisa diragukan lagi. Berbagai karya sudah tidak asing lagi dan telah banyak menghiasi ruang-ruang pamer yang di adakan di Jogja maupun luar Jogja. Data diperoleh dengan cara menayangkan media belajar menggunakan laptop dan memberikan lembar evaluasi. Selanjutnya ahli media menjalankan program media belajar dan setelah itu memberikan masukan secara tertulis maupun secara lisan mengenai visualisasi maupun layout yang ada di dalam media pembelajaran.

Saran yang diberikan oleh ahli media berupa perbaikan kesalahan penulisan kata yang ada di dalam media pembelajaran. Beberapa saran mengenai pemrograman dan pemaksimalan area layout juga diberikan untuk memaksimalkan media yang telah dibuat. Selanjutnya peneliti melakukan tindak lanjut berupa revisi maupun perbaikan yang dilakukan sesuai dengan saran dari ahli media. Saran tersebut dilakukan untuk memperbaiki kesalahan-kesalahan yang ada pada media saat belum diberikan saran oleh ahli media.

Setelah dilakukan revisi sesuai dengan saran dari ahli media, kemudian ahli media melakukan penilaian. Penilaian terhadap media oleh ahli media dilakukan untuk mendapatkan kelayakan media pembelajaran yang dinilai dari aspek tampilan dan pemrograman. Data yang telah diperoleh kemudian diolah untuk mendapatkan hasil dari penilaian ahli media. Hasil validasi produk oleh ahli media berupa rerata skor yang diberikan untuk aspek tampilan dan pemrograman. Hasil penilaian dapat dilihat pada Tabel 3 di bawah ini.

Tabel 3. Hasil Penilaian Kualitas Produk oleh Ahli Media

\begin{tabular}{|c|c|c|c|}
\hline Aspek Penilaian & $\begin{array}{c}\text { Jumlah } \\
\text { Rerata }\end{array}$ & Rerata & Kategori \\
\hline Aspek Tampilan & 95,00 & 4,52 & $\begin{array}{l}\text { Sangat } \\
\text { Baik }\end{array}$ \\
\hline $\begin{array}{l}\text { Aspek } \\
\text { Pemrograman }\end{array}$ & 41,00 & 4,10 & Baik \\
\hline Jumlah & & 8,62 & \\
\hline Rerata Keseluruhan & & 4,31 & $\begin{array}{l}\text { Sangat } \\
\text { Baik }\end{array}$ \\
\hline
\end{tabular}


Berdasarkan Tabel 3 di atas, rerata penilaian hasil validasi ahli media pada aspek kualitas tampilan sebesar 4,52 termasuk ketegori "Sangat Baik". Rerata penilaian aspek pemrograman sebesar 4,10 termasuk kriteria "Baik". Rerata keseluruhan hasil validasi ahli materi sebesar 4,31 termasuk kriteria "Sangat Baik".

Selanjutnya setelah melalui tahap penilaian dari para ahli, selanjutnya dilakukan uji coba skala kecil. Uji coba skala kecil dilakukan kepada siswa kelas 8 Sekolah Menengah Pertama 1 Jetis sebanyak 30 orang. Uji coba skala kecil dilaksanakaan di ruang laboratorium komputer sekolah. Siswa diberikan kesempatan melihat dan mengoperasikan media pembelajaran selama 30 menit. Kemudian peneliti membagikan angket yang selanjutnya diisi oleh siswa untuk memberikan penilaian mengenai media pembelajaran. Hasil uji coba skala kecil penilaian terhadap aspek pembelajaran diperoleh rerata sebesar 4,25 termasuk dalam kriteria "Sangat Baik". Secara keseluruhan pada tahap uji coba skala kecil diperoleh penilaian dengan rerata skor 4,45 termasuk dalam kriteria "Sangat Baik" lebih jelas dapat dilihat pada tabel 4 di bawah ini.

Tabel 4. Skor Keseluruhan Uji Coba Kelompok Kecil

\begin{tabular}{|c|c|c|c|}
\hline Aspek Penilaian & $\begin{array}{l}\text { Jumlah } \\
\text { Rerata }\end{array}$ & Rerata & Kategori \\
\hline Aspek Tampilan & 45,45 & 4,54 & $\begin{array}{l}\text { Sangat } \\
\text { Baik }\end{array}$ \\
\hline Aspek Isi/Materi & 31,83 & 4,55 & $\begin{array}{c}\text { Sangat } \\
\text { Baik }\end{array}$ \\
\hline $\begin{array}{l}\text { Aspek Pembel- } \\
\text { ajaran }\end{array}$ & 46,76 & 4,25 & $\begin{array}{l}\text { Sangat } \\
\text { Baik }\end{array}$ \\
\hline Jumlah & & 13,34 & \\
\hline Rerata Keseluruhan & & 4,45 & $\begin{array}{c}\text { Sangat } \\
\text { Baik }\end{array}$ \\
\hline
\end{tabular}

Uji coba skala besar dilakukan pada siswa kelas 8 di dua sekolah berbeda, yaitu di SMP N 1 Bantul dan SMP N 1 Imogiri. Jumlah keseluruhan siswa dalam uji coba sekala besar ini adalah 57 siswa dengan jumlah 28 siswa di SMP Negeri 1 Bantul dan sisanya sebanyak 29 siswa di SMP Negeri 1 Imogiri. Uji coba dilaksanakaan di ruang laboratorium komputer masing-masing sekolah. Siswa diberikan kesempatan melihat dan mengoperasikan media belajar selama 30 menit. Kemudian peneliti membagikan angket yang selanjutnya diisi oleh siswa untuk memberikan penilaian mengenai me- dia belajar. Tujuan dilakukan uji coba kelompok besar adalah untuk mengetahui kekuatan, kelemahan, kekurangan ataupun kesalahan yang ada pada produk media. Pada uji coba skala besar secara keseluruhan di kedua SMP yaitu di SMPN 1 Bantul dan SMPN 1 Imogiri, penilaian terhadap produk media diperoleh retara sebesar 4,49 termasuk dalam kriteria "Sangat Baik", untuk lebih jelasnya dapat dilihat pada Tabel 5 di bawah ini.

Tabel 5. Hasil Penilaian Uji Coba Skala Besar

\begin{tabular}{lcc}
\hline $\begin{array}{c}\text { Hasil Uji Coba } \\
\text { Skala Besar }\end{array}$ & Rerata & Kategori \\
\hline SMP N 1 Bantul & 4,54 & Sangat Baik \\
SMP N 1 Imogiri & 4,43 & Sangat Baik \\
$\quad$ Jumlah & 8,97 & \\
Rerata keseluruhan & 4,49 & Sangat Baik \\
\hline
\end{tabular}

Penilaian produk diberikan oleh tiga guru Penjasorkes yang ada di SMP Negeri 1 Jetis, 1 Bantul, dan 1 imogiri. Penilaian dilaksanakan dengan uji praktek oleh tiga guru saat kegiatan belajar mengajar. Guru mempraktekkan media dengan menggunakan alat bantu laptop dan proyektor di kelas sebelum praktek di lapangan. Pembelajaran menggunakan media dilakukan selama 30 menit. Setelah melakukan pembelajaran dengan media di dalam ruangan, kemudian guru mengajak siswa untuk mempraktekkan apa yang telah di pelajari di dalam kelas. Setelah pembelajaran selesai guru diberikan angket untuk kemudian di isi sesuai dengan apa yang dirasakan setelah mempraktekkan pembelajaran menggunakan media tersebut. Tujuan dilakukan uji tersebut adalah untuk mengetahui kebermanfaatan media pembelajaran bola voli apabila diterapkan dalam proses belajar mengajar.

Tabel 6. Hasil Penilaian Guru Pada Media Pembelajaran

\begin{tabular}{lccc}
\hline \multicolumn{1}{c}{$\begin{array}{c}\text { Penilaian } \\
\text { Guru }\end{array}$} & $\begin{array}{c}\text { Jumlah } \\
\text { Rerata }\end{array}$ & Rerata & Kriteria \\
\hline SMP N 1 Jetis & 12,90 & 4,30 & $\begin{array}{c}\text { Sangat } \\
\text { Baik }\end{array}$ \\
SMP N 1 & 13,76 & 4,59 & $\begin{array}{c}\text { Sangat } \\
\text { Baik } \\
\text { Bantul }\end{array}$ \\
SMP N 1 & 13,55 & 4,52 & $\begin{array}{c}\text { Sangat } \\
\text { Baik }\end{array}$ \\
Imogiri Jumlah & & 13,40 & $\begin{array}{c}\text { Sangat } \\
\text { Baik }\end{array}$ \\
\multicolumn{2}{c}{ Rerata keseluruhan } & 4,47 & \\
\hline
\end{tabular}


Hasil penilaian diperoleh rerata sebesar 4,47 termasuk dalam kriteria "Sangat Baik". Kesimpulan dari penilaian guru pada media pembelajaran adalah media sangat baik saat digunakan dalam proses pembelajaran. Dengan mengaplikasikannya pada proses belajar mengajar seorang guru dapat menyampaikan materi dengan cara yang tidak biasa. Cara tersebut dinilai dapat meningkatkan ketertarikan siswa terhadap materi bola voli. Ketertarikan yang besar kepada materi memberikan nilai tambah terhadap semangat siswa dalam mengikuti kegiatan pembelajaran Penjasorkes. Pengaplikasian media pembelajaran di dalam proses kegiatan belajar mengajar dapat dilakukan dengan memberikannya di ruang kelas atau juga bisa di lapangan secara langsung.

Selanjutnya uji keefektivan dilakukan melalui pretest dan postest untuk mengetahui seberapa besar pengaruh media terhadap prestasi siswa. Pelaksanaan pretest dan posttest dalam penelitian ini tidak dimaksudkan untuk menguji kefektivitas secara mendalam seperti yang diterapkan pada penelitian eksperimen, yaitu menghadirkan kelas kontrol sebagai pembanding. Pelaksanaan tes pada penelitian yang dilakukan pleh pengembang hanya sekedar membandingkan pretest dan posttest peserta didik sebagai dasar mengetahui pengaruh media pada kemampuan siswa dan untuk memantapkan kesimpulan bahwa produk media tersebut layak.

Sebelum produk media pembelajaran diujicobakan, pengembang terlebih dahulu mengadakan pretest dari materi pembelajaran dalam produk media pembelajaran. Pretes dilakukan untuk mengetahui kemampuan awal dari siswa sebelum guru mengajarkan materi dengan bantuan komputer. Hasilnya akan dibandingkan dengan setelah melakukan pembelajaran dengan media komputer. Pretes yang dilakukan terhadap siswa terbagi dalam 2 tahap yaitu pada uji coba skala kecil dan uji coba skala besar. Pretest dan posttest dilakukan dengan menggunakan lembar soal pilihan ganda yang dilakukan dalam waktu 15 menit sebelum mempelajari dan sesudah para siswa mempelajari media pembelajaran teknik dasar bola voli. Hasil uji keefektivan adalah sebagai berikut; (1) rerata skor pretest sebelum siswa menggunakan media pembelajaran ini adalah sebesar 5,4, (2) sesudah siswa menggunakan media pembelajaran teknik dasar bola voli diperoleh rerata skor posttest sebesar 8,6, (3) efektivitas produk dilihat dari pencapaian seli- sih rerata skor pretest terhadap rerata skor posttest pada penggunaan media pembelajaran teknik dasar bola voli adalah sebesar 3,2. Hal ini membuktikan bahwa telah terjadi peningkatan pemahaman siswa terhadap materi bolavoli sekaligus membantu siswa dalam proses belajar. Peningkatan rerata skor tersebut juga menunjukkan bahwa media pembelajaran teknik dasar bola voli untuk siswa Sekolah Menengah Pertama tersebut mempunyai pengaruh terhadap siswa terutama untuk materi pelajaran bola voli.

Pengembangan media belajar teknik dasar bola voli untuk siswa Sekolah Menengah Pertama yang menggunakan software utama adobe flash CS5 telah dikembangkan sesuai dengan proses tahapan pengembangan yang dilakukan melalui serangkaian uji coba untuk memperoleh data sebagai dasar untuk merevisi produk media pembelajaran. Setelah melalui prosedur pengembangan tersebut, media belajar teknik dasar bola voli untuk siswa Sekolah Menengah Pertama mempunyai kualitas yang lebih baik setelah dilakukan revisi dan perbaikan-perbaikan. Penyusunan produk media telah disesuaikan dengan kurikulum tingkat Sekolah Menengah Pertama. Hal tersebut menjadi dasar dan acuan dalam proses penyusunan media pembelajaran teknik dasar bola voli. Ma-teri yang ada di media disajikan dengan tam-pilan menarik yang akan menggugah minat siswa saat mempelajari keterampilan teknik dasar bola voli dalam proses kegiatan belajar mengajar. Pertimbangan penyampaian materi juga dilakukan dengan mengedepankan pem-belajaran teknik yang paling mudah menuju kompleks. Hal tersebut dimaksudkan agar sis-wa dapat dengan runtut mempelajari materi teknik dasar bola voli yang ada di dalam stan-dar kompetensi dan kompetensi dasar di ting-kat Sekolah Menengah Pertama.

Menurut siswa media pembelajaran teknik dasar bola voli ini sangat menarik digunakan dalam belajar karena penggunaan media khususnya untuk pembelajaran Penjasorkes masih sangat terbatas. Para siswa juga menyatakan bahwa materi yang terkandung di dalamnya seperti contoh gerakan yang diberikan dapat membantu siswa memahami gerakan teknik dasar bola voli. Penggunaan teks, foto dan video membantu siswa memahami isi materi secara detail. Keunggulan media pembelajaran teknik dasar bola voli yaitu bahwa kapasitas file tidak terlalu besar. Program media pembelajaran teknik dasar bola voli terbukti 
se-cara nyata dapat mingkatkan pemahaman sis-wa mengenai materi pelajaran bola voli

Media pembelajaran teknik dasar bolavoli untuk siswa SMP yang dihasilkan dalam pengembangan ini adalah sebagai berikut:

\section{Bagian Isi Program}

Produk yang dihasilkan bernama media belajar teknik dasar bola voli untuk siswa Sekolah Menengah Pertama.

Media pembelajaran ini berisi materi teknik dasar bola voli yaitu, teknik pasing atas, pasing bawah, servis atas, servis bawah, smash, dan membendung (blocking) serta di tambah dengan pembelajaran gerakan kombinasi. Media pembelajaran ini dilengkapi dengan soal evaluasi sesuai dengan materi.

Materi dalam media pembelajaran ini disajikan dengan materi yang diperagakan oleh model serta ditampilkan dalam format video, didukung desain menarik dan mudah digunakan oleh siswa maupun guru sehingga dapat meningkatkan minat belajar siswa.

\section{Bagian Fisik}

Media pembelajaran dikemas dalam satu keping Compact Disc yang memuat unsur teks, gambar, suara, video dan animasi. Media tersebut dapat dioperasikan menggunakan komputer yang telah dilengkapi dengan $C D$ ROOM. Isi media disusun secara sistematis mulai dari halaman pembuka/intro, petunjuk penggunaan dan menu utama yang berisi pendahuluan, pengantar, materi, profil, dan evaluasi. Media pembelajaran ini dapat dioperasikan menggunakan komputer dengan spesifikasi minimal sistem operasi Windows XP, Mac OS, resolusi 1024 x 800 pixel, processor Pentium IV 1,66 Ghz, $512 \mathrm{Mb}$ of RAM, VGA on board $32 \mathrm{Mb}$, HDD $40 \mathrm{~Gb}$, dan telah terinstal aplikasi adobe flash player versi 9.0.

Penggunaan media pembelajaran dapat diaplikasikan dengan dua cara, yaitu dapat dilakukan di dalam ruangan maupun di luar ruangan. Pengaplikasian media di dalam ruangan dapat dilaksanakan dengan mengumpulkan siswa ke dalam kelas, kemudian guru memberikan materi pelajaran taknik dasar bola voli selama 1 jam pelajaran kemudian pada jam berikutnya disusul dengan mempraktekkannya di lapangan. Sedangkan pengaplikasian media pada pembelajaran di lapangan yaitu guru disarankan membawa laptop, memberikan materi mengenai salah satu materi pelajaran teknik dasar bola voli selama 1 jam pel- ajaran, kemudian pada jam berikutnya bisa siswa melakukan praktek sesuai dengan teori teknik dasar yang telah disampaikan. Proses kegiatan belajar mengajar akan semakin baik lagi apabila setiap siswa mempunyai software media pembelajaran teknik dasar bola voli yang mana masing-masing siswa telah ditugaskan oleh guru pada pertemuan berikutnya untuk belajar secara mandiri di luar jam pelajaran.

Pengkolaborasian media pembelajaran taknik dasar bola voli dapat dilakukan dengan metode demonstrasi. Sebelum seorang guru mendemonstrasikan pembelajaran materi teknik dasar bola voli, dapat di awali dengan pembelajaran secara teori menggunakan media pembelajaran. Hasil simulasi dengan pembagian waktu 1 jam pelajaran dengan pembelajaran media dan di lanjutkan dengan praktik di lapangan tersebut efektif dilakukan saat proses kegiatan belajar mengajar. Pembelajaran seperti yang telah dikemukakan di atas tentunya memerlukan peralatan yang memadai, seperti perangkat keras berupa leptop maupun proyektor untuk menampilkan gambar secara maksimal.

\section{Daftar Pustaka}

Anonim. (2012). Meaning and definition of physical education, body fitness and health education. http://bodyfitnesshealth.com/meaning-and-definition-ofphysical-education/. Diunduh tanggal 22 Juli 2012.

Anonim.(2012).http://www.adobe.com/devnet/ flash/articles/flash_cs5_createfla.html. Diunduh tanggal 19 Juli 2012.

Bergeles, Nikos. (2010). Performance effectiveness in complex II of olympiclevel male and female volleyball players. Grigoris National and Kapodistrian University of Athens, Faculty of Physical Education and Sports Science, Greece. Jurnal. Tersedia: http://www.fivb.org/EN/Medical/Docu ment/2010_IJVR.pdf. Diunduh tanggal 29 Maret 2013.

Fathurrohman, Pupuh. (2007). Strategi belajar mengajar melalui penanaman dan konsep islami. Bandung: PT Refika Aditama.

Gall, Meredith D., Gall, Joyce P., \& Borg, Walter R. (2003). Educational re- 
search: an introduction $\left(7^{\text {th }}\right.$ ed $)$. United States of America: Pearson Inc.

Mahendra, Agus. (2003). Falsafah pendidikan jamani.http://www.ditplb.or.id/profile. php?id=65. Diunduh tanggal 22 Juli 2012.

Mulyati. (2005). Psikologi belajar. Yogyakarta: Andi Offset.

Newby, T. J. et all. (2004). Instructional technology for teaching and learning. New Jersey: Prentice Hall Inc.

Riduwan. (2007). Skala pengukuran variabelvariabel penelitian. Bandung: Alfabeta.

Smaldino, S. E., Lowther, D. L., \& Russell, J. D. (2008). Intructional technology and media for learning $\left(9^{\text {th }}\right.$ ed.) New Jersey: Pearson.
Sugihartono dkk. (2007). Psikologi pendidikan. Yogyakarta: UNY Press.

Sukardjo. (2005). Evaluasi pembelajaran. Diktat mata kuliah evaluasi pembelajaran. Prodi TP PPs UNY. Tidak diterbitkan.

Sumiati. (2008). Metode pembelajaran. Bandung: Wacana Prima.

Vaibhav Rai, (2013). A study on physiological characteristics of national volleyball players. Research on Humanities and Social Sciences. Jurnal. Tersedia: http://www.iiste.org/Journals/index.ph p/RHSS/article/view/4997/5093. Diunduh tanggal 27 April 2013.

Walker, D. F. \& Hess, R. D. (2000). Instructional software. California: Wadsworth Publishing Company, Belmot. 